\title{
Tutorial Alat Pelindung Diri Dalam Pembuatan Masker Dari Kain Perca Untuk mengurangi Penularan Virus covid-19
}

\author{
Didik Aribowo ${ }^{1}$, Desmira ${ }^{2}$, Ratna Ekawati ${ }^{3}$ \\ ${ }^{1,2,3}$ Pendidikan Teknik Elektro, Fakultas Keguruan dan Ilmu Pendidikan \\ Universitas Sultan Ageng Tirtayasa, Serang 42117, Indonesia \\ e-mail: ${ }^{1}$ d_aribowo@untirta.ac.id, ${ }^{2}$ desmira@untirta.ac.id \\ ${ }^{3}$ ratnaekawati@untirta.ac.id
}

\begin{abstract}
Abstrak
Munculnya virus covid 19 awal januari 2021 diindonesia membuat Alat Pelindung Diri (ADP) kelangkaan masker kesehatan yang dijual ditoko-toko mengalami harga yang melonjak dan mengalami kelangkaan dimana-mana, dengan latar belakang ini dosen dan mahasiswa mempunyai inisiatif bagaimana memberikan solusi bagi masyarakat yang sangat membutuhkan masker tersebut. Metode penelitian ini menggunakan pendekatan kualitatif, dimana penelitian ini menggunakan latar alamiah dengan maksud menafsirkan fenomena yang terjadi dan dilakukan dengan jalan melibatkan metode yang ada. Hasil penelitian ini adalah menghasilkan masker dari kain perca sehngga dibagikan kemasyarakat yang membutuhkan diwilayah setempat. Kesimpulan dari kegiatan ini adalah penggunaan Alat Pelindung Diri (ADP) masker sangatlah penting untuk membantu memutus penyebaran Covid-19 .
\end{abstract}

Kata Kunci: Virus Covid-19, Alat Pelindung Diri (ADP), Kain perca

\begin{abstract}
The emergence of the covid 19 virus in early January 2021 in Indonesia made Personal Protective Equipment (ADP) the scarcity of health masks sold in shops experiencing soaring prices and experiencing scarcity everywhere, with this background lecturers and students have the initiative how to provide solutions for people who are very desperate. need the mask. This research method uses an approach approach, where this research uses a natural background by discussing the phenomena that occur and is carried out by using existing methods. The result of this research is to produce masks from patchwork so that they are distributed to people in need in the local area. The conclusion of this activity is that the use of Personal Protective Equipment (ADP) masks is useful to help break the spread of Covid-19.
\end{abstract}

Keywords: Covid-19 virus, Personal Protective Equipment (ADP), patchwork

\section{Pendahuluan}

Di awal tahun 2020 ini, dunia dikagetkan dengan kejadian infeksi berat dengan penyebab yang belum diketahui, yang berawal dari laporan dari Cina kepada World Health Organization (WHO) terdapatnya 44 pasien pneumonia yang berat di suatu wilayah yaitu Kota Wuhan, Provinsi Hubei, China, tepatnya di hari terakhir tahun 2019 Cina(Ciotti et al., 2020). Dugaan awal hal ini terkait dengan pasar basah yang menjual ikan, hewan laut dan berbagai hewan lain. Pada 10 Januari 2020 penyebabnya mulai teridentifikasi dan didapatkan kode genetiknya yaitu virus corona baru. Penelitian selanjutnya menunjukkan hubungan yang dekat dengan virus corona penyebab Severe Acute Respitatory Syndrome (SARS) yang mewabah di Hongkong pada tahun 2003, hingga WHO menamakannya sebagai novel corona virus (nCoV19) (Hay,

This work is licensed under a Creative Commons Attribution-ShareAlike 4.0 International License.

Published by LPPM Universitas Bina Sarana Informatika 
2020). Di Indonesia sendiri kasus pertama terjadi pada tanggal 01 Maret 2020. Setelah muncul pemberitaan mengenai Warga Negara Indonesia yang diketahui positif Covid-19. Masyarakat menjadi waspada dan mulai menjaga jarak. Sehingga relasi pada jaringan menjadi berkurang dan beberapa anggota jaringan perlahan bergeser menjadi semi-isolate. Setelah menyebarnya virus dan meningkatanya jumlah penderita Covid-19, pemerintah Indonesia mengumumkan agar warga negara melakukan social distancing dan mengeluarkan anjuran Protkol Kesehatan, Seperti menjaga jarak, rajin cuci tangan, dan selalu menggunakan masker sebagai Alat Pelindung Diri (ADP) apabila keluar rumah(Irawan et al., 2020). Penggunaan masker merupakan bagian dari rangkaian komprehensif langkah pencegahan dan pengendalian yang dapat membatasi penyebaran penyakit-penyakit virus saluran pernapasan tertentu, termasuk COVID-19 (Putri, 2020)(Rosalina, 2021). Masker sebagai Alat Pelindung Diri (ADP) dapat digunakan baik untuk melindungi orang yang sehat (dipakai untuk melindungi diri sendiri saat berkontak dengan orang yang terinfeksi) atau untuk mengendalikan sumber (dipakai oleh orang yang terinfeksi untuk mencegah penularan lebih lanjut)(Armiani et al., 2020). Namun, penggunaan masker sebagai Alat Pelindung Diri (ADP) saja tidak cukup memberikan tingkat perlindungan atau pengendalian sumber yang memadai(Armiani et al., 2020)(Rosalina, 2021). Karena itu, langkah-langkah lain di tingkat perorangan dan komunitas perlu juga diadopsi untuk menekan penyebaran virus-virus saluran pernapasan. Terlepas dari apakah masker digunakan atau tidak(Armiani et al., 2020), kepatuhan kebersihan tangan, penjagaan jarak fisik, dan langkah-langkah pencegahan dan pengendalian infeksi (PPI) lainnya sangat penting untuk mencegah penularan COVID-19 dari orang ke orang. Dokumen ini memberikan informasi dan panduan mengenai penggunaan masker sebagai Alat Pelindung Diri (ADP) dalam pelayanan kesehatan, bagi masyarakat umum, dan saat melakukan perawatan di rumah. World Health Organization (WHO) telah menyusun panduan khusus mengenai strategistrategi PPI dalam pelayanan kesehatan, fasilitas perawatan jangka panjang (FPJP), dan perawatan di rumah. Penularan dan penyebaran virus COVID-19 semakin dipahami setiap harinya. Sifat utama COVID-19 adalah penyakit saluran pernapasan dan spektrum infeksi virus ini berkisar dari orang yang mengalami gejala-gejala bukan saluran pernapasan yang sangat ringan hingga penyakit saluran pernapasan akut berat, sepsis disertai disfungsi organ, dan kematian. Beberapa orang yang terinfeksi dilaporkan tidak mengalami gejala sama sekali. Menurut bukti saat ini, penyebaran virus COVID-19 terjadi terutama antara orang melalui rute droplet (percikan) dari saluran pernapasan dan kontak. Penularan droplet terjadi saat seseorang berada dalam kontak erat (dalam jarak 1 meter) dengan orang yang terinfeksi dan terjadi pajanan droplet saluran pernapasan yang kemungkinan terinfeksi, misalnya melalui batuk, bersin, atau kontak sangat erat dengan orang tersebut sehingga agen infeksi masuk melalui titik-titik seperti mulut, hidung, atau konjungtiva (mata)(Pratiwi, 2020). Penyebaran juga dapat terjadi melalui fomit di lingkungan langsung orang yang terinfeksi karena itu, penyebaran virus COVID19 dapat terjadi secara langsung melalui kontak dengan orang yang terinfeksi atau secara tidak langsung melalui kontak dengan permukaan lingkungan langsung atau bendabenda yang digunakan untuk atau oleh orang yang terinfeksi (misalnya, stetoskop atau termometer).

Pada saat ini, Indonesia sedang mengalami masa-masa sulit dalam melawan pandemi virus covid-19 yang semakin hari semakin menyebar luas. Masyarakat sangat khawatir akan kesehatannya masing-masing, selain itu pemerintah juga menghimbau agar masyarakat tidak mengunjungi tempat tempat keramaian terlebih dahulu ataupun keluar rumah jika memang tidak ada keperluan yang mendesak. Sehingga hal ini menyebabkan banyak masyrakat yang merasa tidak bebas karena adanya batasan-batasan dan larangan-larangan untuk tidak keluar rumah ataupun beraktivitas diluar rumah sebagai Alat Pelindung Diri (ADP). Banyak sekali 
para pekerja, mahasiswa, murid-murid sekolah dasar hingga murid-murid sekolah menengah keatas harus menjalankan semua kegiatannya dari rumah masing-masing demi kebaikan dan kesehatan semua masyarakat di Indonesia.Namun masih banyak juga masyarakat yang tidak dapat mematuhi aturan tersebut, dengan alasan bahwa mereka bosan di rumah dan alasan lain sebagainya. Hal tersebut membuat masyarakat bertekad keluar rumah untuk mencari hiburan seperti shopping di pusat perbelanjaan mall, nongkrong bersama teman-teman hingga ada pula yang berlibur ke luar kota bahkan ke luar negeri. Maka ini sangat memperburuk situasi penyebaran virus covid-19 di Indonesia. Ketika kasus virus covid-19 di Indonesia semakin bertambah banyak, masyarakat justru menyalahkan pemerintah bahwasanya pemerintah tidak tegas dan tidak becus dalam mengurus masyarakatnya. Lantas banyak masyarakat yang menjadi panik, hingga akhirnya mereka membutuhkan alat sebagai Alat Pelindung Diri (ADP) untuk mencegah penyebaran virus covid-19 tersebut. Masyarakat mulai mencari-cari masker, namun terjadi kelangkaan pada barangbarang tersebut. Barang-barang yang tadinya sangat mudah ditemui dan dijumpai dimana-mana kini barang tersebut sangat amat langka dan harganuya pun juga sangat mahal di pasaran. Setelah dilakukan pengusutan, ternyata terdapat oknum penimbun masker. Mereka sengaja melakukan hal tersebut untuk mencari keuntungan dalam mewabahnya pandemi virus covid-19 ini tanpa memikirkan masyarakat lainnya dan tim medis yang sedang berjuang menangani pasien-pasien positif virus covid-19. Hal ini seharusnya tidak terjadi di negara Indonesia ini, masih banyak masyarakat yang memiliki sikap individualisme yang selalu mementingan dirinya dan egonya masing-masing, tidak dapat memanusiakan manusia dengan sebenarnya. Masyarakat Indonesia saat ini dapat dikatakan sebagai masyarakat yang kurang memiliki rasa peduli terhadap sesamanya, tindakan ini sangat miris dan tidak seharusnya terjadi, apalagi saat ini Indonesia sedang berada dimasa-masa yang memprihatinkan. Dampak Yang Ditimbulkan Saat Terjadinya Kelangkaan Masker akibat mewabahnya pandemi virus covid-19 di Indonesia serta terjadinya penimbunan masker sebagai Alat Pelindung Diri (ADP) yang cukup besarbesaran oleh para oknum tidak bertanggungjawab tersebut. Maka, berdampak juga pada pabrikpabrik besar yang memproduksi makser dan handsanitizer. Mereka tidak dapat memproduksinya secara banyak, karena mereka juga kesulitan mencari pasok bahan-bahan baku yang akan digunakan untuk memproduksi masker. Sedangkan bagi para penimbun masker, mereka sangat senang karena mendapat banyak uang dari hasil penjualan barangbarang yang telah ditimbunnya. Hal ini sangat menyebabkan kesenjangan sosial dan ketidakadilan, dimana letak hati dan rasa kemanusiaan mereka. Tidak ada tindakan kolektivisme sama sekali dalam hal ini. Padahal banyak negara-negara tetangga yang meskipun kekurangan masker dan handsanitizer tetapi mereka tetap mengusahakan dengan membagibagikannya secara cuma-cuma dan gratis kepada seluruh masyarakatnya. Selain itu, sekarang masyarakat juga mulai melakukan berbagai langkah atau upaya pencegahan, salah satunya dengan menggunakan masker saat berada di tempat umum. Namun sayangnya, sejak pandemi ini mulai merebak, ketersediaan masker pun mengalami kelangkaan. Kelangkaan ini akhirnya membuat harga masker sebagai Alat Pelindung Diri (ADP) bernilai jual tinggi pasaran. Namun hal ini tidak perlu dikhawatirkan, jika tak mendapatkan stok masker, sebab Alat Pelindung Diri (ADP) ini sebenarnya bisa dibuat di rumah. Selain lebih murah, cara membuatnya pun terbilang mudah karena Anda hanya memanfaatkan kain perca alias kain sisa yang sudah tidak dipakai lagi.Demikian dengan melonjak dan langkanya harga masker diindonesia maka dari itu kelompok 21 KKM Reguler Universitas Sultan Ageng Tirtayasa 2020 bekerja sama dengan masyarakat dalam pembuatan Masker dari Kain Perca, agar semua orang bisa menggunakan masker dengan mudah tanpa adanya hambatan untuk melaksanakan Protokol Kesehatan. 


\section{Metode}

Penelitian ini menggunakan pendekatan kualitatif. Dimana penelitian ini menggunakan latar alamiah dengan maksud menafsirkan fenomena yang terjadi dan dilakukan dengan jalan melibatkan metode yang ada. Agar hasil penelitian dapat digunakan untuk menafsirkan fenomena yang ada maka perlu pendekatan dengan menggunakan teknik analisis yang dimana dalam hal ini dilakukan pendekatan penalaran kritis. Berikutnya teknik analisis penelitian ini melibatkan interpretasi dengan menggunakan pendekatan kualitatif (penalaran kritis). Jenis dan sumber data berasal dari buku literature dan jurnal terkait secara induktif. Analisis secara induktif ini digunakan untuk menemukan kenyataan-kenyataan jamak sebagai yang terdapat dalam data dan lebih dapat membuat hubungan peneliti dan responden menjadi eksplisit, dapat dikenal dan akuntabel.

\section{Hasil dan Pembahasan}

Pengendalian dan Pencegahan Penyakit (CDC) mengatakan, petugas kesehatan harus menggunakan masker buatan sendiri sebagai upaya terakhir ketika tidak ada peralatan pelindung yang tersedia. Untuk menghindari terjadinya kelangkaan masker bagi petugas medis, CDC kemudian menyarankan untuk memilih masker kain sebagai Alat Pelindung Diri (ADP). Pada awalnya, organisasi kesehatan dunia, WHO, maupun CDC tidak menyarankan untuk menggunakan masker sebagai Alat Pelindung Diri (ADP) jika Anda tidak sakit atau tidak bekerja di tempat yang berpotensi tinggi untuk terpapar penyakit.Membagikan masker sebagai Alat Pelindung Diri (ADP) dan poster tentang protokol kesehatan. Namun berbagai penelitian terbaru tentang perkembangan virus corona atau Covid-19 menyatakan bahwa dikhawatirkan ada kelompok yang tanpa disadari rentan menyebarkan virus corona. Kelompok yang disebut asymptomatic dan presymptomatic adalah orang-orang yang telah positif corona namun tidak atau belum menunjukkan gejala apa pun. Oleh karena itu, masker kain dianjurkan oleh pemerintah untuk mencegah semakin meluasnya penularan virus. Saat ini, kita tidak tahu lagi, siapa yang sakit, siapa yang sehat. Yang terinfeksi bisa tidak menunjukkan gejala, bahkan tidak sadar jika terinfeksi. Langkah terbaik adalah melindungi orang lain dari risiko terinfeksi dengan menggunakan masker sebagai Alat Pelindung Diri (ADP) setiap keluar rumah. Masker kain sebagai Alat Pelindung Diri (ADP) bisa dibuat sendiri, dari kain perca ataupun kaus bekas. Jika Anda suka menjahit, dapat dijahit, namun jika tidak, yang diperlukan adalah kain/kaus bekas dan karet elastis/ikat rambut elastis.

Tabel 1. Cara Membuat Masker Dari Kain Perca Alat Pelindung Diri (ADP)

\begin{tabular}{ll} 
No $\begin{array}{l}\text { Bahan-bahan } \\
\text { dibutuhkan: }\end{array}$ & $\begin{array}{l}\text { Kain Perca adalah Kain yang terbuat } \\
\text { dari potongan kain besar atau kain sisa } \\
\text { guntingan yang berasal dari pembuatan } \\
\text { pakaian, kerajinan, atau produk tekstil } \\
\text { lainnya. }\end{array}$ \\
\hline$\quad$ Kain Perca & Kegiatan
\end{tabular}




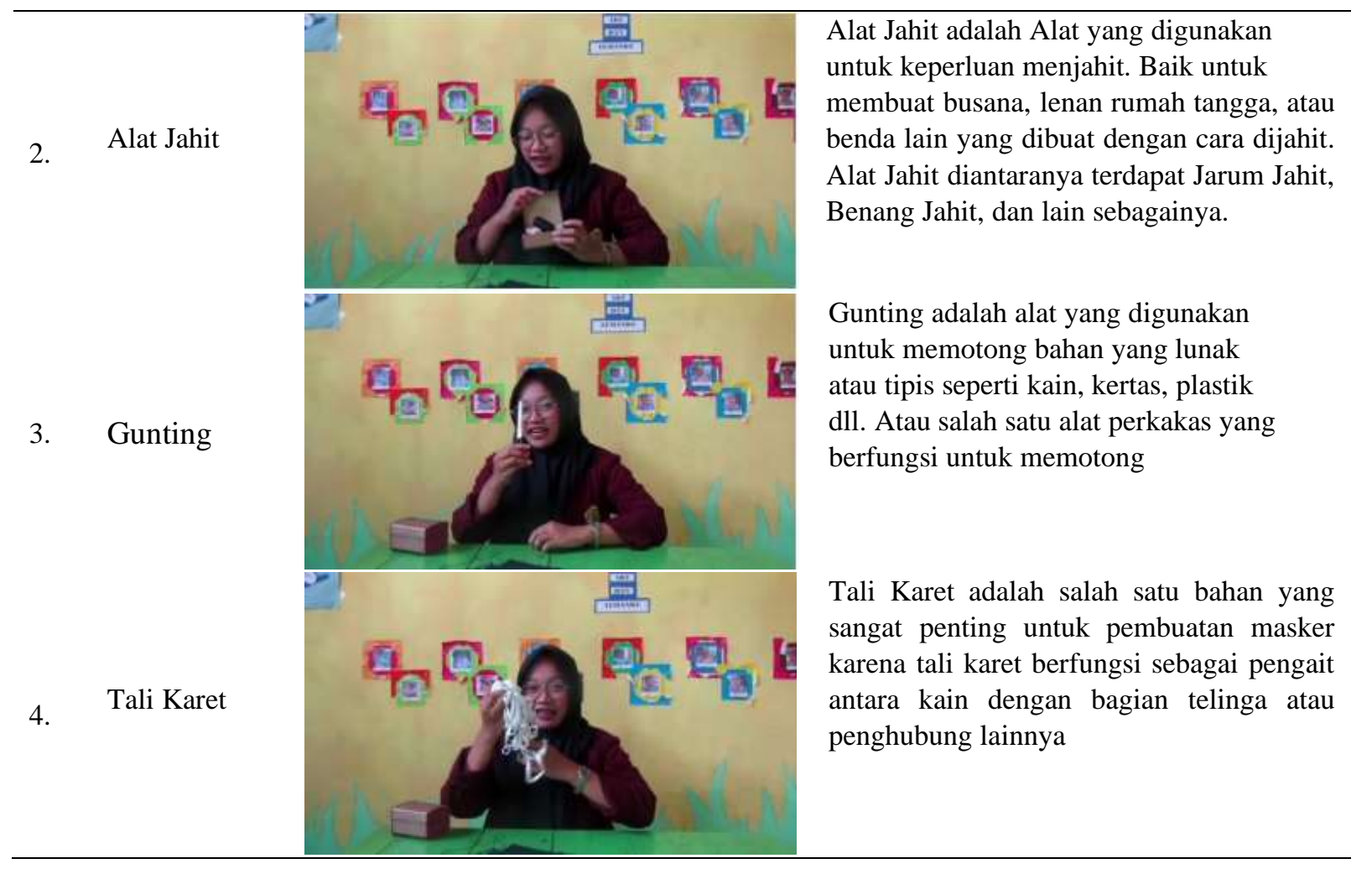

Langkah-Langkah Membuat Masker dari Kain Perca sebagai Alat Pelindung Diri (ADP)

1. Pertama-tama, siapkan kain perca yang sudah disediakan dan disesuaikan sebelumnya.

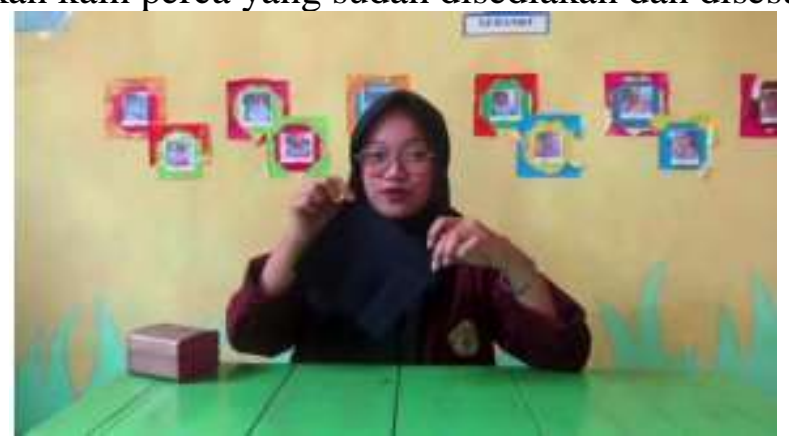

2. Kemudian lipat bagian atas dan bawah Kain Perca sebagai Alat Pelindung Diri (ADP)

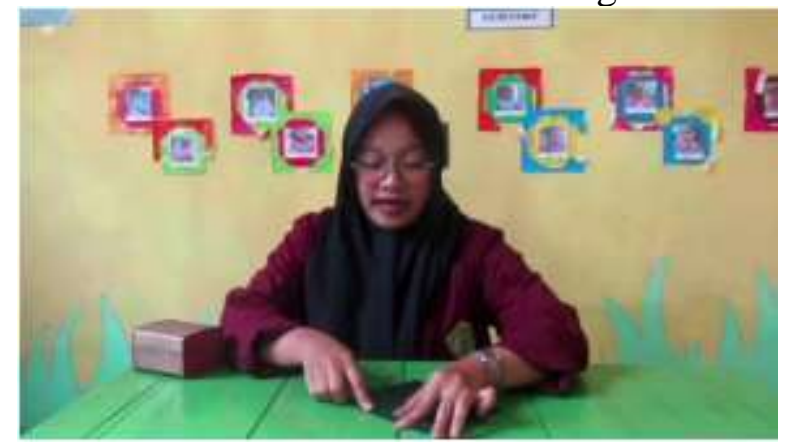

3. Untuk bagian yang sudah dilipat, selanjutnya jahit rapih kedua bagian dari kain tersebut menggunakan benang serta jarum jahit, untuk hasil yang lebih bagus dan rapih juga bisa menggunakan mesin jahit. 


\section{ABDITEKNIKA}

Jurnal Pengabdian Kepada Masyarakat
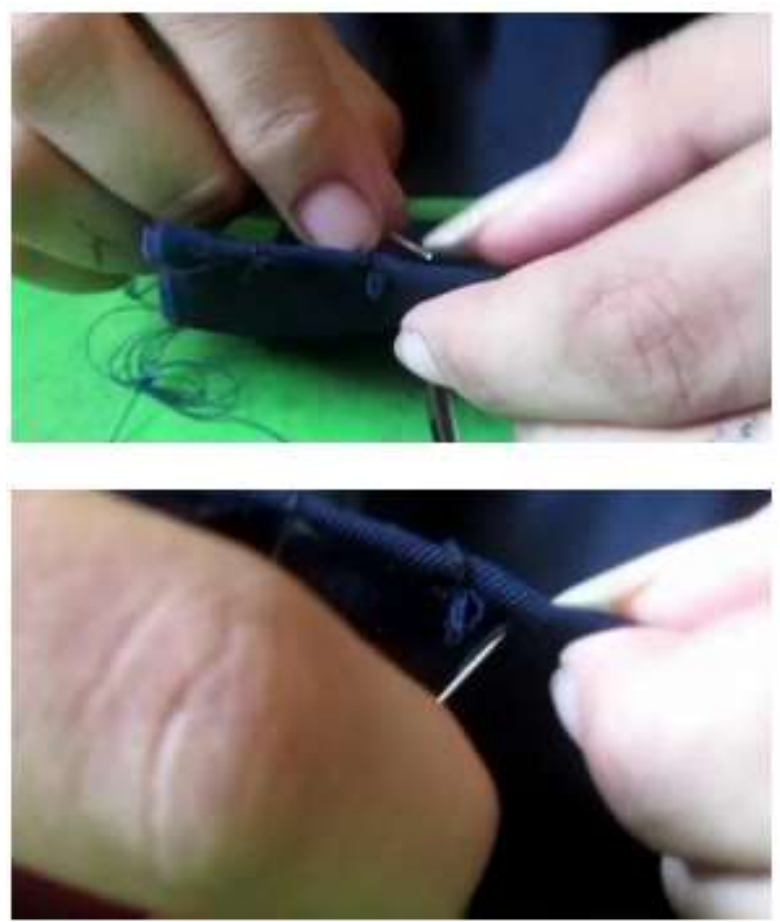

4. Apabila kedua bagian sisi atas dan bawahnya sudah dijahit, selanjutnya lipat beberapa bagian dari kain perca tersebut

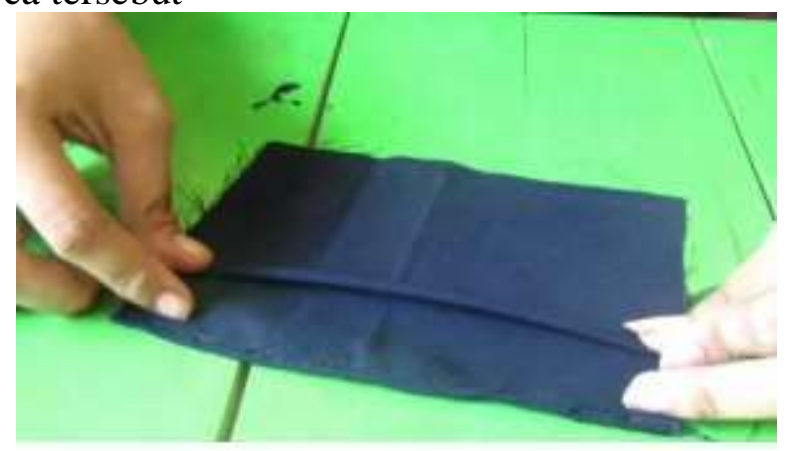

5. Setelah dilipat menjadi beberapa bagian, jahit bagian ujung sisi kain perca yang sudah dilipat tadi.
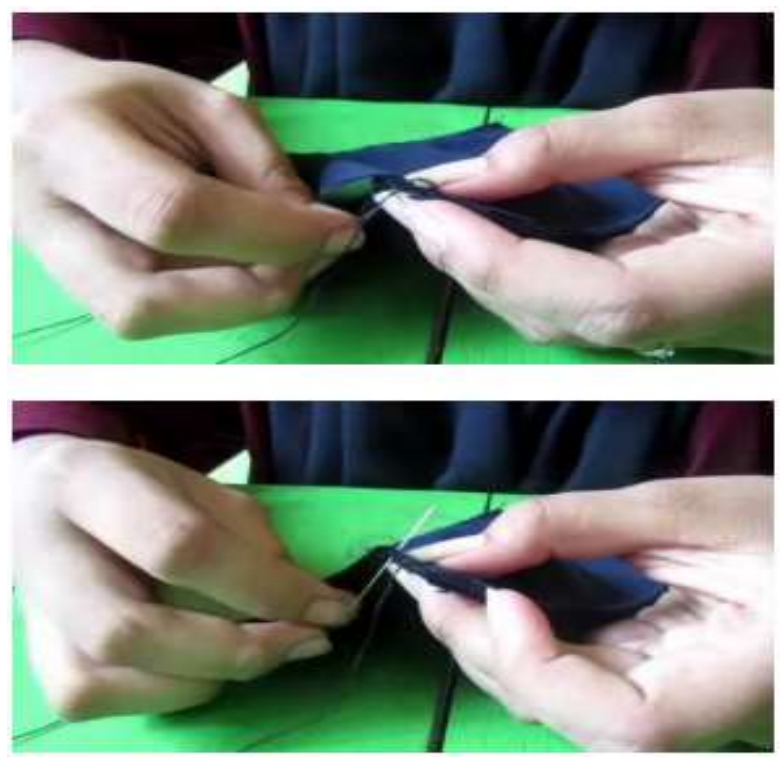


\section{ABDITEKNIKA}

Jurnal Pengabdian Kepada Masyarakat

6. Kemudian setelah kain perca sudah terbentuk, selanjutnya gunting karet tali disesuaikan dengan ukuran wajah dari si pengguna masker.

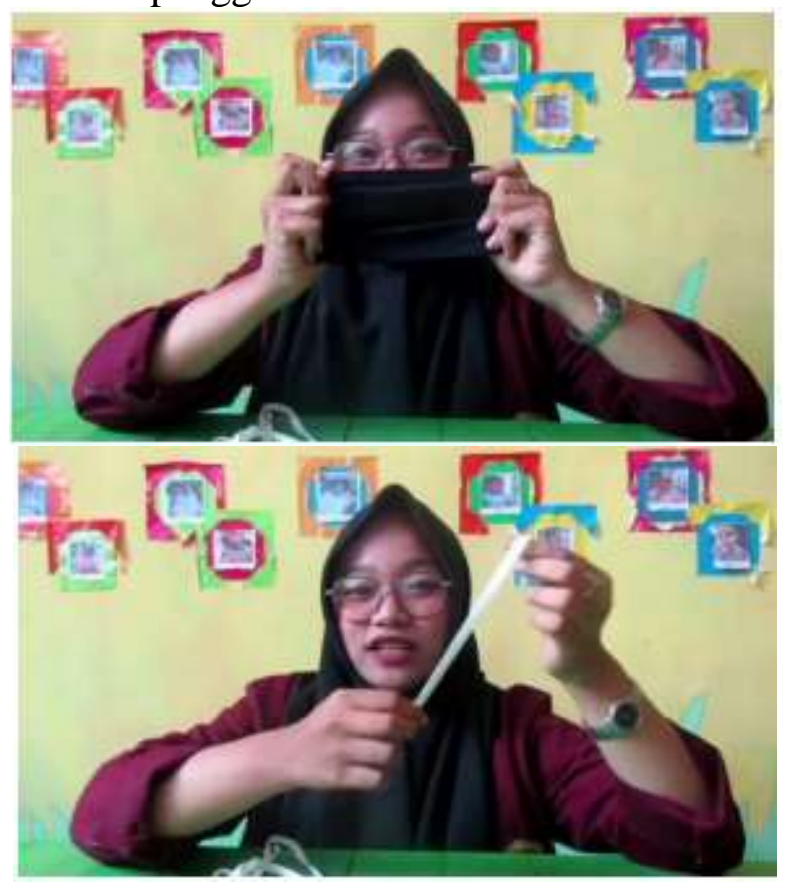

7. Dan langkah terakhir jahit tali karet yang sudah disesuaikan pada bagian sisi atas dan bawah kain masker yang sudah dibentuk.
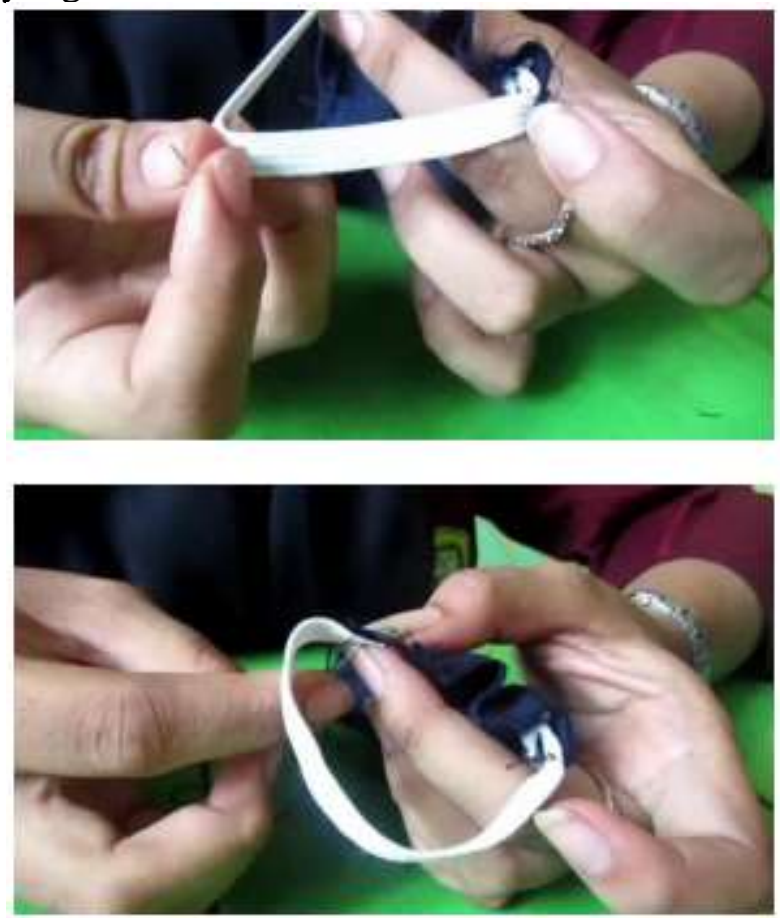

8. Selesai. Masker siap untuk digunakan. 


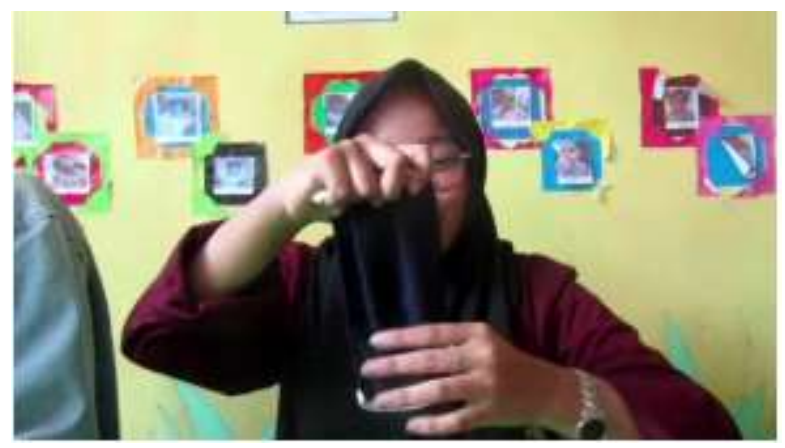

\section{Kesimpulan}

Berdasarkan uraian di atas dapat disimpulkan bahwa penggunaan masker sebagai Alat Pelindung Diri (ADP) sangatlah penting untuk membantu memutus penyebaran Covid-19. Penggunaan masker juga sudah menjadi salah satu anjuran protokol kesehatan yang ditetapkan pemerintah. Maka dari itu kita harus melaksanakan protokol kesehatan. Seiring perkembangan Covid-19 keberadaan masker kini mulai langka jika ada pasti harga akan sedikit lebih tinggi dari biasanya. Namun hal ini tidak perlu dikhawatirkan, jika tak mendapatkan stok masker, sebab Alat Pelindung Diri (ADP) ini sebenarnya bisa dibuat di rumah. Selain lebih murah, cara membuatnya pun terbilang mudah karena Anda hanya memanfaatkan kain perca alias kain sisa sebagai Alat Pelindung Diri (ADP) yang sudah tidak dipakai lagi. Tata cara pembuatan masker dari kain perca dan sudah membuat Video Tutorial Membuat Masker dari Kain Perca dan bisa dilihat di Link YouTube https://youtu.be/Pts6pvXv1v

\section{Penghargaan}

Penulis mengucapkan terima kasih peserta KKM, Universitas Sultan Ageng Tirtayasa Tahun 2020 Pabuaran. Dr. Rusmana,.Ir.,MP yang telah memberikan kesempatan untuk saya membimbing mahasiswa KKM Reguler Universitas Sultan Ageng Tirtayasa Tahun 2020. Serta semua pihak mahasiswa KKM Universitas Sultan Ageng Tirtayasa Tahun 2020 yang telah terlibat langsung dalam pelaksanna KKM regular .

\section{Daftar Pustaka}

Armiani, S., Fajri, S. R., Sukri, A., \& Pidiawati, B. Y. (2020). Pelatihan Pembuatan Masker Sebagai Upaya Antisipasi Penyebaran Covid-19 di Desa Anyar Kabupaten Lombok Utara. Jurnal Pengabdian UNDIKMA, 1(1), 22-27. https://doi.org/10.33394/jpu.v1i1.2550

Ciotti, M., Ciccozzi, M., Terrinoni, A., Jiang, W. C., Wang, C. Bin, \& Bernardini, S. (2020). The COVID-19 pandemic. Critical Reviews in Clinical Laboratory Sciences, 57(6), 365388. https://doi.org/10.1080/10408363.2020.1783198

Hay, S. (2020). COVID-19 scenarios for the United States. Nature Medicine. https://doi.org/10.1101/2020.07.12.20151191

Irawan, D., Triana, N., Suwarni, L., \& ... (2020). Edukasi Protokol Kesehatan dan Strategi Pemasaran Online Melalui Program Kemitraan Masyarakat di Era Pandemi Covid-19. JMM (Jurnal Masyarakat ..., 4(4), 7-9. http://journal.ummat.ac.id/index.php/jmm/article/view/2636

Pratiwi, A. D. (2020). Gambaran Penggunaan Masker di Masa Pandemi Covid-19 Pada Masyarakat di Kabupaten Muna. Literacy Institute, 52-57. https://www.mendeley.com/catalogue/ee828287-9e25-37b2-aeb8- 
a92b94ed347c/?utm_source=desktop\&utm_medium=1.19.4\&utm_campaign=open_catal og\&userDocumentId=\%7Bb93b070a-115c-4260-854c-e57f42c47e86\%7D

Putri, S. I. (2020). Studi Literatur: Efektivitas Penggunaan Masker Kain dalam Pencegahan Transmisi Covid-19. Jurnal Kesehatan Manarang, 6(khusus), 10.

Rosalina, V. (2021). Gerakan Donasi 3.000 Masker Kain Dan Edukasi Penggunaan Masker Kain Dalam Upaya Menekan Penyebaran Covid-19. Kaibon Abhinaya : Jurnal Pengabdian Masyarakat, 3(1), 53-57. https://doi.org/10.30656/ka.v3i1.2916 